\title{
Spatial and temporal variation of fish assemblage associated with aquatic macrophyte patches in the littoral zone of the Ayapel Swamp Complex, Colombia
}

\author{
Variaçáo espacial e temporal da fauna de peixes associada a bancos de macrófitas \\ aquáticas na zona litorânea do Complexo Pantanoso de Ayapel, Colômbia
}

\section{Carlos Mario Marín Avendaño ${ }^{1 *}$ and Néstor Jaime Aguirre Ramírez ${ }^{2}$}

${ }^{1}$ GAIA Group, Environmental School, Faculty of Engineering, University of Antioquia, P.O. Box 1226, Medellín, Cra 55 Av. del Ferrocarril, Colombia

${ }^{2}$ GeoLimna Group, Environmental School, Faculty of Engineering, University of Antioquia, P.O. Box 1226, Medellín, Cra 55 Av. del Ferrocarril, Colombia

*e-mail: carlos.marin@udea.edu.co

Cite as: Marín Avendańo, C.M. and Aguirre Ramírez, N.J. Spatial and temporal variation of fish assemblage associated with aquatic macrophyte patches in the littoral zone of the Ayapel Swamp Complex, Colombia. Acta Limnologica Brasiliensia, 2017, vol. 29, e3.

Abstract: Aim: The purpose of the present study was to examine spatial and temporal variation in fish assemblage structure associated with aquatic macrophytes in the littoral zone of the ASC. Methods: Specimens were caught between January 2008 and February 2009, over four limnimetric moments, using both cast net and seine net. Data on the temperature, electrical conductivity, $\mathrm{pH}$ and dissolved oxygen was recorded for the characterization of the water mass in the sites. Results: A total of 34,151 specimens from 44 species were collected. The most abundant species were Eigenmannia virescens, Astyanax caucanus, Astyanax fasciatus, Roeboides dayi and Cyphocharax magdalenae, which together accounted for more than $75 \%$ of the sample. Temporal and spatial comparisons showed variation in the environmental conditions and highlighted the existence of heterogeneous abiotic conditions $(\mathrm{p}<0.05)$. However, the multiple comparisons test showed the existence of homogeneous spatial conditions $(\mathrm{p}>0.05)$ regarding the fish assemblage structure. The multivariate analysis showed no significant relationship between existing environmental conditions and the fish assemblage $(p=0.04)$. The analysis also showed the absence of a relationship between the fish assemblage and environmental variables with respect to the flood pulse and sampling sites ( $p>0.05)$. Conclusion: The uniformity of the fish communities that inhabit aquatic macrophyte patches in the littoral region of the ASC may be related to the availability of suitable habitat in structural terms, that probably supports a more abundant and varied wildlife.

Keywords: ichthyofaunal; abundance; Eichhornia spp; floodplains; shallow water.

Resumo: Objetivo: Neste estudo foi analisada composição e a abundância da fauna de peixes associadas a bancos de macrófitas aquáticas em seis setores do Complexo Pantanoso de Ayapel. Métodos: Os espécimes foram obtidos entre janeiro de 2008 e fevereiro de 2009, durante quatro momentos limnimétricos, utilizando-se tarrafa e rede de arrasto. Foram obtidos dados de temperatura, condutividade eléctrica, $\mathrm{pH}$ e oxigênio dissolvido para a caracterizaçáo da massa de água nos locais. Resultados: No período de estudo 34,151 exemplares de 44 espécies foram colectadas. As espécies mais abundantes foram Eigenmannia virescens, Astyanax caucanus, Astyanax fasciatus, Roeboides dayi e Cyphocharax magdalenae, que representaram mais de $75 \%$ da amostra. Comparaçóes temporais 
e espaciais mostraram uma variação de condiçôes ambientais que realça a existência de condiçóes heterogêneas $(p<0,05)$. No entanto, espacialmente, o teste de comparação múltipla revelou a existência de condiçóes homogêneas $(p>0,05)$ associados com a estrutura da fauna de peixes. A análise multivariada empregada não mostrou uma relação significativa entre as condiçôes ambientais existentes e as assembléias de peixes $(p=0,04)$. A análise também mostrou a ausência de relação entre o conjunto de peixes e as variáveis ambientais de acordo com o pulso de inundação e locais de amostragem ( $>00,05)$. Conclusóes: A uniformidade das comunidades de peixes que habitam bancos de macrófitas aquáticas na regiáo litorânea do ASC pode estar relacionada com a disponibilidade de habitat adequado em termos estruturais, que provavelmente sustentam uma fauna mais abundante e variada.

Palavras-chave: ictiofauna; abundância; Eichhornia spp; planícies de inundação; águas rasas.

\section{Introduction}

Swamps are influenced by the hydrological seasonality of each basin, that in turn generate variations in the environment and consequently in the surrounding habitats (Schmidt-Mumm \& Janauer, 2014). Swamps do not always offer ideal conditions for the fish fauna to grow (Lopes et al., 2015). However, the riparian zones, areas of high biodiversity and diversity of environmental processes, have a wide range of influences on swamp habitat. These affect biodiversity and a range of processes such as fish reproduction and predation (Pusey \& Arthington, 2003). At the same time, aquatic plants increase the spatial complexity of these ecosystems, favoring the presence of numerous fish species (Pelicice et al., 2005; Willis et al., 2005; Neiff et al., 2009; Thomaz \& Cunha 2010). The effect of flood cycles on the structure of aquatic communities (Junk \& Wantzen, 2004; Neiff et al., $2008,2009)$ is attenuated through the use of floating aquatic vegetation by the fish in the littoral area of the Ayapel Swamp Complex (ASC). This biotope acts as a refuge, nursery and storage of resources coming from detritus, periphyton, and macro and micro invertebrates (Poi de Neiff \& Neiff, 2006; Sánchez-Botero et al., 2007; Montoya-Moreno \& Aguirre-Ramírez, 2009; Villabona-González et al., 2011).

Numerous studies have evaluated the relationship between fish and aquatic vegetation in tropical floodplains (Thomaz \& Cunha, 2010). In Colombia, knowledge of ecology in the swamps is incipient and fish research has focused on fisheries, given their economic importance for riverside communities that derive their livelihood from this activity (Montoya \& Aguirre 2009). Only three studies considering the relationship between fish and aquatic vegetation have been conducted in Colombian aquatic environments (Correa, 2008; Rivera-Rondón et al., 2008, Pérez-Mayorga \& Prada-Pedreros, 2011). Apart from the study conducted by Ríos-Pulgarín et al. (2008), no systematic investigation of the fish fauna associated with the aquatic vegetation of the ASC has been carried out.

The current study was conducted in an environment where the riparian zone is affected by the removal of native plant communities and the introduction of populations of Eichhornia crassipes and $E$ azurea, two invasive plants that represent about $70 \%$ of the aquatic vegetation growing on the surface of the water. Both Eichhornia spp populations reach their growth peak during the period of high waters. Extensive (average 7-10 m length) and dense patches of Eichhornia spp (floating and rooted) are located along the littoral zone of ASC, providing a biotope that is used by a great diversity of organisms. The structural simplicity of the root system of E. azurea, located on the littoral water surface, contrasts with the pleustonic E. crassipes roots that can extend down into the water column, reaching lengths over a meter and representing up to $44 \%$ of the total plant biomass (Reddy \& Tucker, 1983).

The hypothesis stated is that if the fish assemblage associated with the pleuston in the littoral area of the ASC is influenced by changes in the water level, which in turn induce changes in the physicochemical conditions, the food supply, and flow patterns in the system, then fish assemblages will show a spatial heterogeneity evidenced by significant differences in its composition and its characteristics.

\section{Material and Methods}

\subsection{Study area}

The ASC is located in the department of Cordoba, in the north coastal region of Colombia

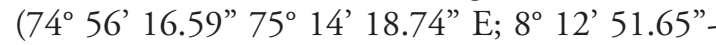
$8^{\circ} 29^{\prime} 0.49^{\prime \prime} \mathrm{N}$ ). The swamp complex is connected to the San Jorge River in the lower part of the basin (Figure 1). The climate is characterized by temperatures ranging from $25-34^{\circ} \mathrm{C}$ and annual rainfall ranging between 2,400 and $2,900 \mathrm{~mm}$. There are two well-defined seasons: The rainy season (from April to November), and the dry 


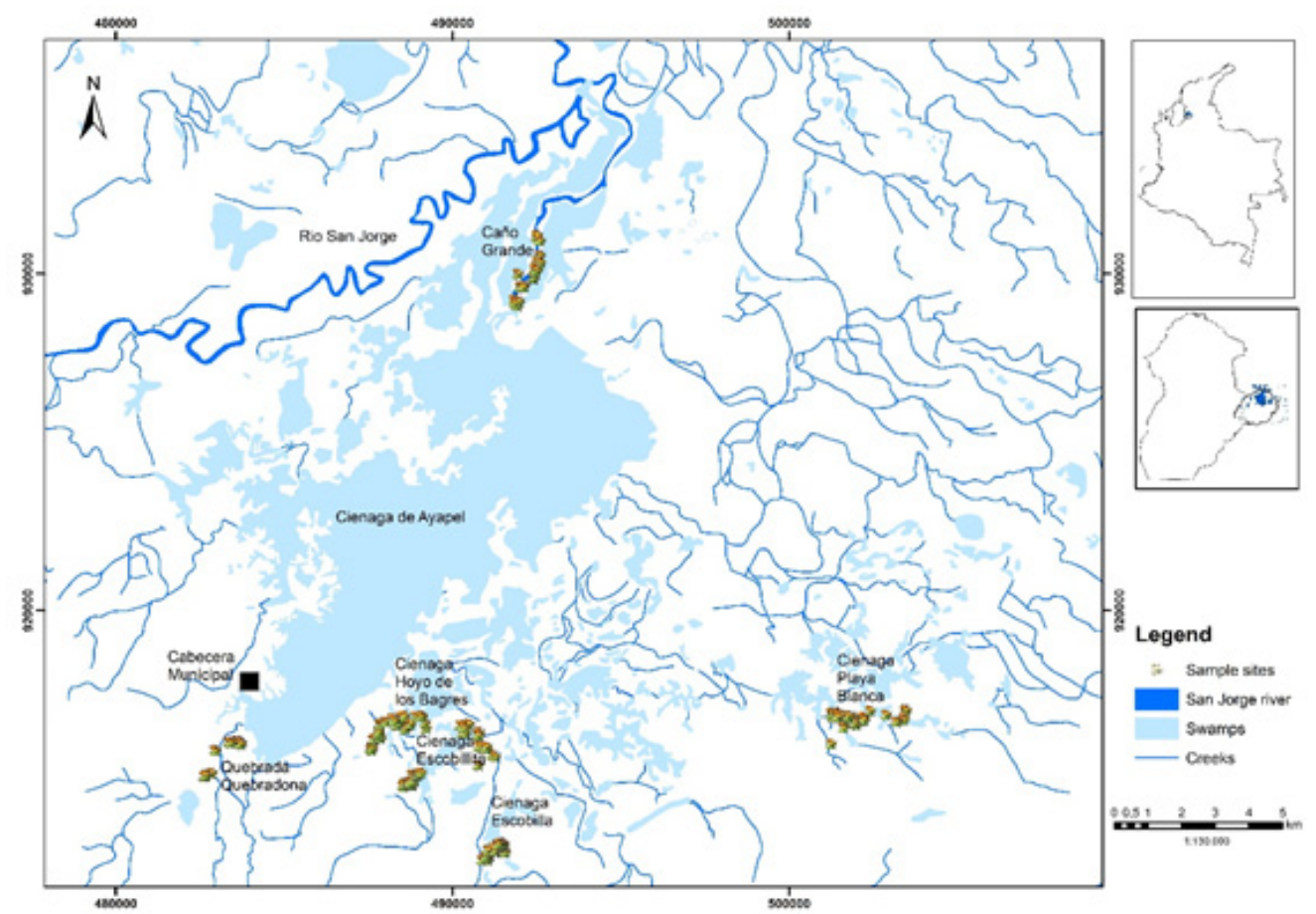

Figure 1. Sampling sites in Ayapel swamp complex: Caño Grande (CG), Quebrada (QQ) Quebradona, Hoyo los Bagres Swamp (HBS), Escobillita Swamp (EtS), Escobillas Swamp (EIS) and Playa Blanca Swamp (PBS).

season (from December to March) (Aguirre et al., 2005). This shallow system has its own hydrological system and has marked changes in the flooded area (20.6 to $\left.130 \mathrm{~km}^{2}\right)$, water level $(0.2-7.7 \mathrm{~m})$ and stored volume (50-400 $\mathrm{Mm}^{3}$ ) (Aguirre et al., 2005).

\subsection{Fish collections and sampling sites}

Eight sampling campaigns (8 days each), were performed over four limnimetric moments between January 2008 and February 2009 (Table 1). The specimens were collected in six randomly chosen sectors located on the eastern area of the ASC, where $81.8 \%$ of the annual rainfall of the basin is collected (Figure 1).

\subsection{Experimental fishing}

A cast net $(5 \times 4 \mathrm{~m})$ and a seine net $(18 \times 1.7 \mathrm{~m})$ were used during experimental fishing. Both the cast and seine net had a mesh of $10 \mathrm{~mm}$. During each campaign in each sector, thirty attempts with the cast net and three with the beach seine were made both near the outer edge and below pleuston patches dominated by Eichhornia spp. Fish capture was conducted from 6:00h to 18:00h.

Fish specimens were euthanized by immersion in an ice-water bath and later were fixed in 10\% formaline solution. After two days, the fish were preserved in $70 \%$ ethanol for identification in the laboratory. The fish was counted and their individual total length $(\mathrm{mm})$ and weight $(\mathrm{g})$ measured. The identification was made following Eigenmann (1922), Dahl (1971) and Maldonado-Ocampo et al. (2005). Similarly, the migratory habits, economic importance, and degree of threat to the species was identified (Usma et al., 2009; Mojica et al., 2012). Some specimens were deposited in the Ichthyology Collection of the University of Antioquia (CIUA) (collection numbers -143 to 198 and 260 to 263 for the ASC).

\subsection{Limnologic variables}

When the fish capture took place, measurements of water temperature, electrical conductivity, $\mathrm{pH}$ and dissolved oxygen were recorded in the pleuston interstitial area at a depth of $30 \mathrm{~cm}$.

\subsection{Data analysis}

Fish composition, richness $(S)$ and numerical abundance $(\mathrm{N})$ were determined for presence and absence during the day in four limnimetric moments and in six sectors of the ASC. Species diversity was measured considering the Shannon-Wiener diversity index $\left(\mathrm{H}^{\prime}\right)$. In order to determine the permanence of the species in the evaluated sectors, the ecological index of consistency was used and each species was classified as constant $(C>50)$, accessory $(25 \% \leq \mathrm{C} \leq 50 \%)$, or accidental $(\mathrm{C}<25 \%)$ (Dajoz, 2002). 
Table 1. Sampling campaigns in the Ayapel Swamp Complex (ASC) over different limnimetric moments from January 2008 to November 2009.

\begin{tabular}{cccc}
\hline $\begin{array}{c}\text { Sampling } \\
\text { campaign }\end{array}$ & Date & Water level (cm) & Limnimetric moment \\
\hline 1 & January 29-February 4/2008 & 470 & Decreasing Waters (DW) \\
2 & April 8-14/2008 & 270 & Low Waters (LW) \\
3 & July 14-21/2008 & 600 & High Waters (HW) \\
4 & September 8-15/2008 & 590 & High Waters (HW) \\
5 & February 2-9/2009 & 370 & Decreasing Waters (DW) \\
6 & March 25-Abril 1/2009 & 290 & Row Waters (LW) \\
7 & May 6-12/2009 Waters (RW) \\
8 & June 5-12/2009 & 380 & Rising Waters (RW) \\
\hline
\end{tabular}

In order to determine the statistical significance of the temporal and spatial variables on biotic and abiotic factors, non-parametric Friedman test and Wilcoxon's paired comparisons test were conducted.

To establish the relationship between the fish abundance and the physicochemical variables, multivariate statistical analysis was performed using the CANOCO 4.5 software (Ter Braak \& Šmilauer, 2012). All biotic and abiotic data matrices were standardized $(\mathrm{x}-\mathrm{min} / \mathrm{max}-\mathrm{min})$ and converted to their square root $(\sqrt{x}+1)$, so as to minimize the effect of extreme values. In order to reduce the influence of less abundant species, the analysis of the abundance matrix was limited to the most abundant species so that negligible weighting was avoided. To verify the existence of a temporal or spatial ordination between species and abiotic samples, the abundance matrix was submitted to Detrended Canonical Correspondence Analysis (DCCA) and the gradient length was estimated. As the gradient length in DCA was short (1.2), indicating a linear response, Redundancy Analysis (RDA) was used to verify the variability of the fish assemblage structure in relation to the measured environmental factors. Subsequently, selection procedure with Monte Carlo simulations (499 permutations) was used to constrain the final model so that it only included environmental variables significant at $\mathrm{p}<0.05$. The RDA results were presented graphically in a plot of two-dimensional array.

\section{Results}

\subsection{Experimental fishing}

A total of 34,151 specimens representing 10 orders, 25 families and 44 species were collected. $71.2 \%$ of the fish captured were small specimens (size $\leq 100 \mathrm{~mm}$ ) and $28.8 \%$ were medium size (> $100 \mathrm{~mm})$. The largest specimen captured belonged to the species Sternopygus aequilabiatus and had a standard length of $765 \mathrm{~mm}$. The smallest specimen, Poecilia caucana, had a standard length of $9 \mathrm{~mm}$. (Table 2).

Following the definition of Mojica et al. (2012), three introduced species were among the samples: Oreochromis sp, Oreochromis niloticus and Trichopodus pectoralis (6.7\%). In addition, the samples include, in accordance with Usma et al. (2009), 15 migratory species (33.3\%), 17 species recognized for their economic importance (37.8\%), and 11 threatened species $(24.4 \%)$ (Table 2).

Spatial consistency analysis indicated that 30 species were considered constant, 16 of which were present in all sectors. Seven species were defined as accessory, and a further seven species were defined as accidental (Table 2). The comparison between the maximum number of estimated and observed species showed that these were similar (Chao $=49.9$ and Jacknife $=50.8 ; 45$ species $)$.

The fish assemblage was characterized by the presence of few species (e.g., Eigenmannia. virescens, Astyanax caucanus, Astyanax fasciatus, Roeboides dayi, Cyphocharax magdalenae, Triportheus magdalenae, Caquetaia kraussii and Andinoacara latifrons) with many individuals $(\mathrm{n} \geq 1000)$, and many species (27) with few individuals $(\mathrm{n}<100)$.

Characiformes was the dominant order, constituted by 17 species and accounting for $62.7 \%$ and $64.7 \%$ of fish captures and biomass respectively. This was followed by the by the Siluriformes, with 12 species and accounting for $3.0 \%$ and $6.1 \%$ of fish captures and biomass respectively. Cichliformes and Gymnotiformes presented five and four, respectively, accounting for $9.3 \%$ and $10.2 \%$, and $23.5 \%$ and $16.6 \%$ of fish captures and biomass. The remaining orders presented one species by taxa and accounted for very low proportions of catches and biomass $(>1.0 \%$ and $>1.5 \%)$. Characidae accounted for a higher percentage of captures (48.0\%) than Sternopygidae (23.5\%), Curimatidae 


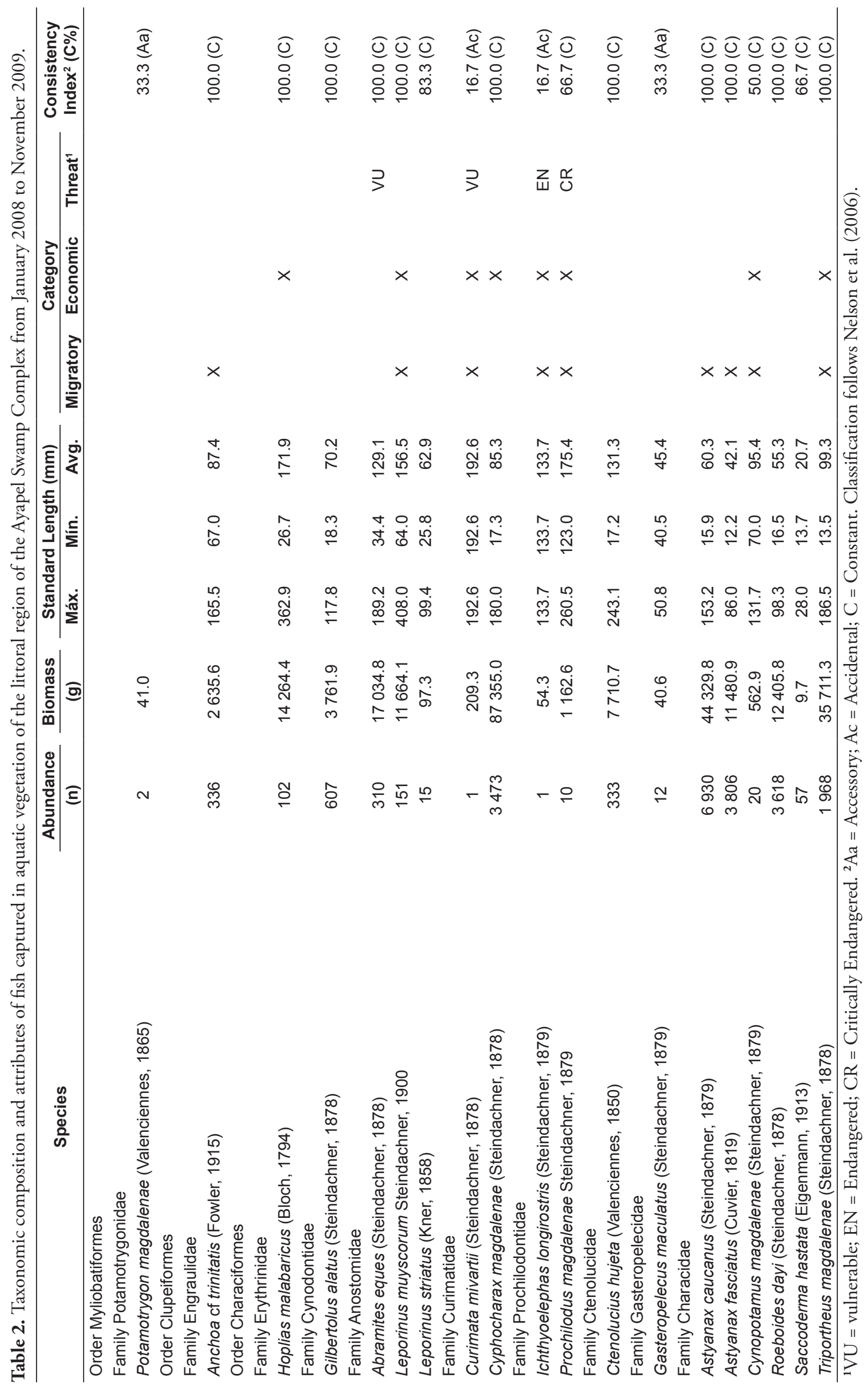




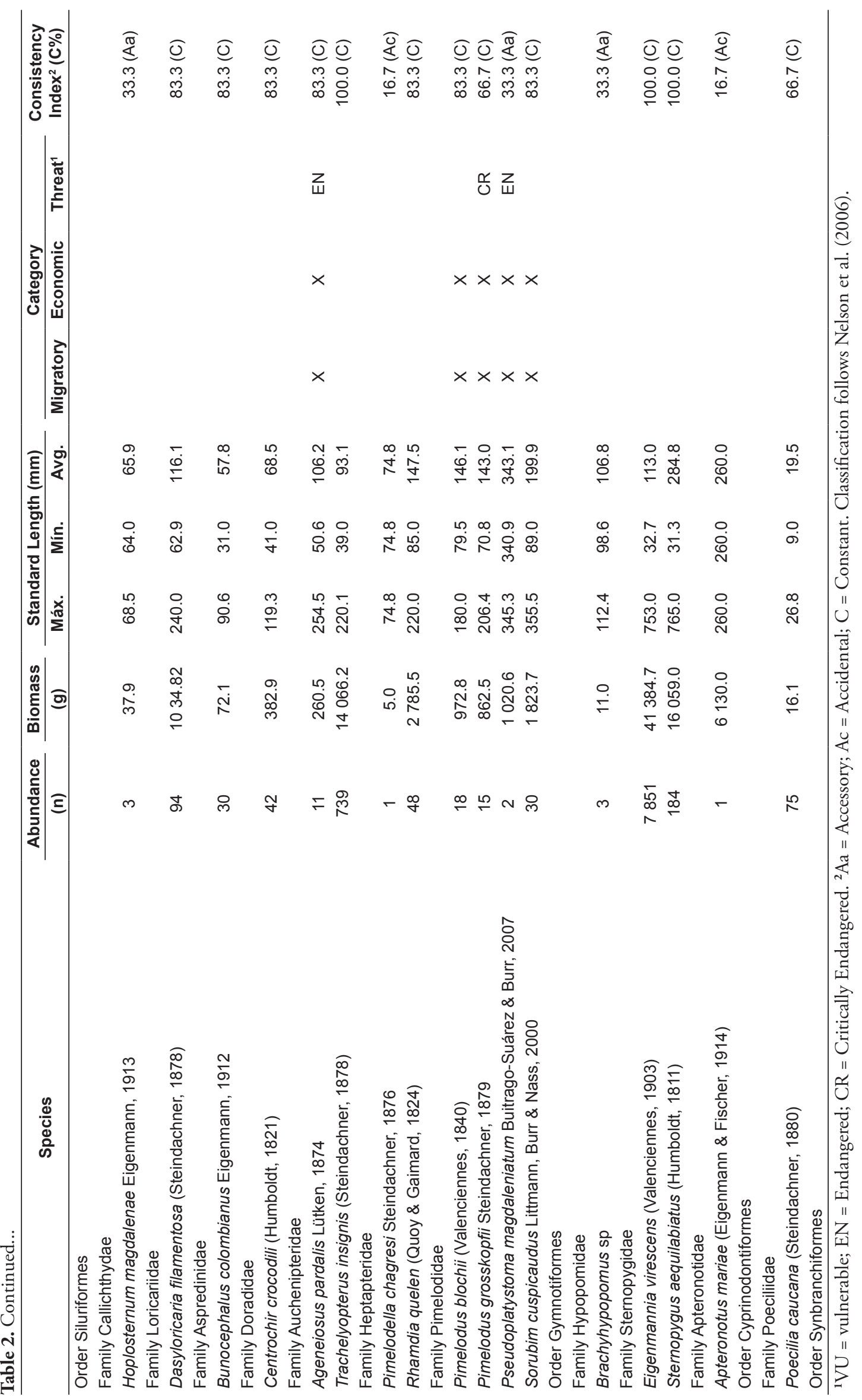


Spatial and temporal variation of fish assemblage associated with aquatic...

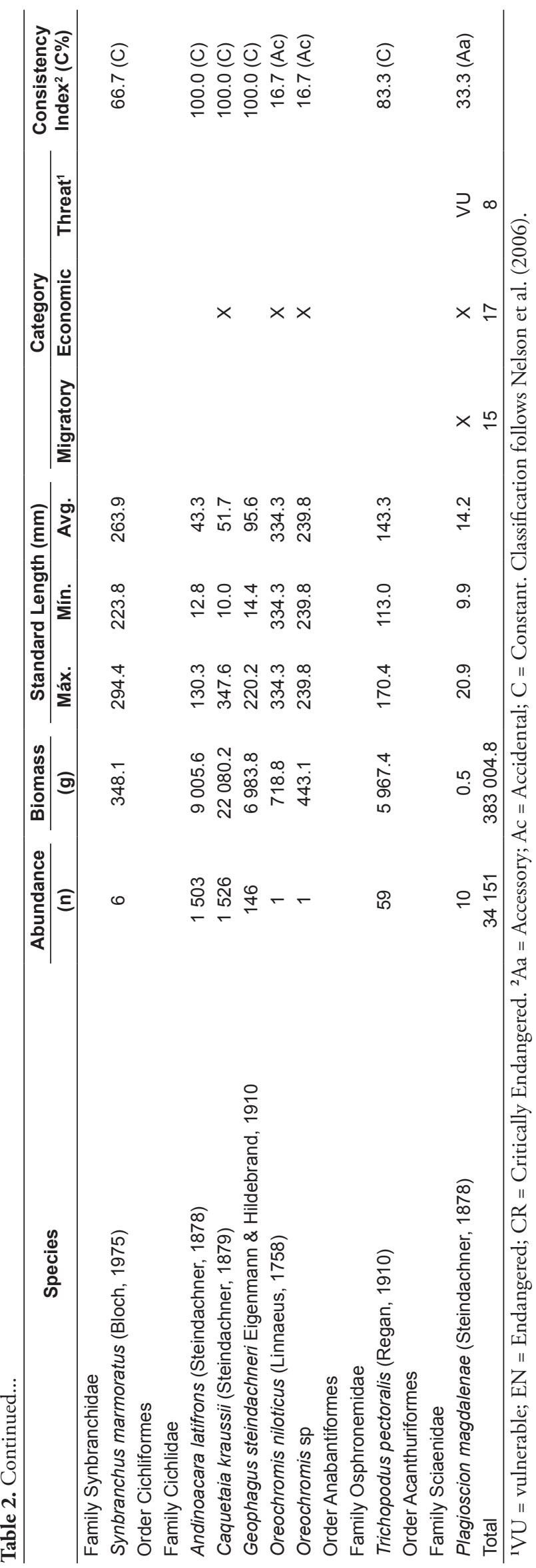


(10.2\%), or Cichlidae (9.3\%). Characidae and Curimatidae, accounted for similar percentages of biomass (27.3\% and $22.9 \%$, respectively), which was a higher percentage of biomass than sternopygids $(1.60 \%)$, cichlids $(2.35 \%)$, and anostomids (3.04\%).

At the species level, contributions to fish capture and biomass were as follows: $23.0 \%$ and $10.8 \%$ for Eigenmannia virescens; 20.3 and $11.6 \%$ for Astyanax caucanus; $11.1 \%$ and $3.0 \%$ for Astyanax fasciatus; $10.6 \%$ and $3.2 \%$ for Roeboides dayi; $10.2 \%$ and $22.8 \%$ for Cyphocharax magdalenae; $5.8 \%$ and 9.3\% for Triportheus magdalenae; $4.5 \%$ and $5.8 \%$ for Caquetaia kraussii; and $4.4 \%$ and $2.4 \%$ for Aequidens latifrons. These species accounted for $89.8 \%$ of all captured fish and $68.9 \%$ of the total biomass.

Specific richness showed a temporal pattern where the greatest number of species were captured in the LW period (36 species) while in the HW period only 27 species were recorded. Spatially, the greatest number of species were captured in the HBS (34 species), and PBS (33 species) sectors, while in EtS and QQ only 29 and 28 species were recorded for each site.

During the study, the species diversity $\left(\mathrm{H}^{\prime}\right)$ registered was 3.3 bits. In temporal terms, diversity varied between 2.8 bits (DW) and 3.5 bits (RW). Spatially, diversity varied between 3.0 bits (CG and $\mathrm{EtS}$ ) and 3.3 bits (QQ).

\subsection{Limnologic variables}

Physicochemical conditions in all sectors are presented in Table 3.

\subsection{Data analysis}

Statistical analysis of the water quality and fish assemblage structure showed significant differences due to the combined effect of changes in the water level and sampling sectors (Friedman ANOVA, $\mathrm{p}<0.05)$. Temporal and spatial comparisons showed the existence of homogeneous (Wilcoxon test $\mathrm{p}>0.05)$ conditions associated with the fish assemblage structure; and heterogeneous (Wilcoxon test $\mathrm{p}<0.05$ ) conditions associated with environmental conditions in the different sectors. Meanwhile, the multiple comparisons showed the existence of homogeneous conditions (Wilcoxon, $\mathrm{p}>0.05$ ) associated only with the assemblage structure in different sectors.

Temporarily, the change in the water level showed an effect on water quality. The electrical conductivity was the variable that most influenced the estimated differences for paired samples $(\mathrm{p}<0.05)$. The physicochemical variables evaluated only showed similar environmental conditions ( $p>0.05$ ) between moments of high levels of water movement (RW vs. DW). Totally different environmental conditions $(p<0.05)$ were evident only at-moments where the waters remained in a limnophase condition (HW and LW).

Table 3. Physicochemical variables in the Ayapel Swamp Complex (ASC) during different limnimetric moments and sampling sectors.

\begin{tabular}{|c|c|c|c|c|c|c|c|c|c|c|c|c|}
\hline \multirow{2}{*}{\multicolumn{2}{|c|}{$\begin{array}{c}\text { Physicochemical } \\
\text { variables }\end{array}$}} & \multicolumn{4}{|c|}{ 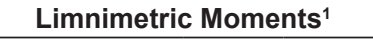 } & \multicolumn{6}{|c|}{ Sectors $^{2}$} & \multirow{2}{*}{ Period } \\
\hline & & HW & DW & LW & RW & HBS & EtS & EIS & PBS & CG & QQ & \\
\hline \multirow{4}{*}{$\begin{array}{c}\text { Temperature } \\
\left({ }^{\circ} \mathrm{C}\right)\end{array}$} & Maximum & 32.6 & 32.8 & 34.7 & 34.5 & 34.7 & 34.2 & 32.6 & 33.4 & 34.5 & 34.2 & 34.7 \\
\hline & Minimum & 27.8 & 27.5 & 28.7 & 28.6 & 29.0 & 28.9 & 27.5 & 28.7 & 28.6 & 28.1 & 27.5 \\
\hline & Average & 30.8 & 30.6 & 31.6 & 31.0 & 31.8 & 30.8 & 30.3 & 31.3 & 30.9 & 30.9 & 31.0 \\
\hline & C.V & 4.1 & 4.4 & 4.9 & 4.5 & 4.4 & 3.6 & 5.0 & 3.4 & 4.9 & 5.0 & 4.6 \\
\hline \multirow{4}{*}{$\begin{array}{l}\text { Electrical } \\
\text { Conductivity } \\
\left(\mu S . \mathrm{cm}^{-1}\right)\end{array}$} & Maximum & 69.2 & 295.2 & 211.0 & 277.6 & 139.4 & 142.9 & 132.6 & 295.2 & 178.4 & 155.4 & 295.2 \\
\hline & Minimum & 10.2 & 33.3 & 29.1 & 60.6 & 17.4 & 10.2 & 11.2 & 17.1 & 33.3 & 18.9 & 10.2 \\
\hline & Average & 29.9 & 111.2 & 89.0 & 125.7 & 67.7 & 65.2 & 72.4 & 159.5 & 95.5 & 73.3 & 88.9 \\
\hline & C.V & 65.5 & 44.6 & 57.8 & 43.7 & 45.5 & 65.1 & 60.8 & 49.8 & 48.0 & 49.4 & 65.9 \\
\hline \multirow{4}{*}{$\mathrm{pH}$ (Units) } & Maximum & 7.0 & 7.7 & 8.7 & 8.3 & 8.3 & 7.7 & 7.6 & 7.4 & 8.7 & 8.7 & 8.7 \\
\hline & Minimum & 5.1 & 7.5 & 6.3 & 6.4 & 5.6 & 5.6 & 5.4 & 5.1 & 6.3 & 6.0 & 5.1 \\
\hline & Average & 6.2 & 6.9 & 7.1 & 7.0 & 6.8 & 6.8 & 6.6 & 6.5 & 6.9 & 7.1 & 6.8 \\
\hline & C.V & 7.5 & 7.8 & 7.6 & 5.9 & 9.8 & 8.8 & 8.4 & 8.2 & 6.9 & 9.4 & 8.9 \\
\hline \multirow{4}{*}{$\begin{array}{l}\text { Dissolved } \\
\text { Oxygen } \\
\text { (mg.L-1) }\end{array}$} & Maximum & 7.1 & 8.8 & 10.7 & 7.1 & 8.8 & 6.9 & 6.5 & 5.7 & 6.8 & 10.7 & 10.7 \\
\hline & Minimum & 0.9 & 3.5 & 2.6 & 2.9 & 2.7 & 3.2 & 2.4 & 0.9 & 3.1 & 4.1 & 0.9 \\
\hline & Average & 3.8 & 5.6 & 5.3 & 5.5 & 5.7 & 5.3 & 4.7 & 3.6 & 4.8 & 6.3 & 5.1 \\
\hline & C.V & 35.8 & 19.9 & 34.7 & 19.4 & 27.0 & 17.0 & 25.1 & 36.7 & 23.7 & 26.8 & 30.7 \\
\hline
\end{tabular}

${ }^{1} \mathrm{HW}=$ High Waters; DW = Decreasing Waters; LW $=$ Low Waters; RW = Rising Waters. ${ }^{2} \mathrm{HBS}=$ Hoyo los Bagres Swamp; EtS = Escobillitas Swamp; ElS = Escobillas Swamp; PBS = Playa Blanca Swamp; CG = Caño Grande; $\mathrm{QQ}=$ Quebrada Quebradona. Data obtained from periodic observations from January 2008 to November-2009. 
Spatially, the water level affected the water quality. Dissolved oxygen was the variable that most influenced the estimated differences between sectors. Similar environmental conditions associated with all physicochemical variables were found between QQ and EtS $(p>0.05)$, between EtS and EIS ( $>0.05)$, and between CG and EtS ( $>>0.05)$. However, completely different environmental conditions were found between PBS and EtS $(\mathrm{p}<0.05)$. In temporal terms, the fish assemblage structure interacting with the patches of aquatic plants in the littoral area of the ASC did not show statistical differences between contrasting limnimetric moments $(p>0.05)$, indicating a greater uniformity.

Temporary homogeneity remained constant in $83.3 \%$ of the contrasted samples when the biomass was assessed, and in $66.7 \%$ of cases when diversity was evaluated, but reduced in $33 \%$ of the contrasted paired samples when richness was considered. Spatially, the fish assemblage structure interacting with the aquatic plants in the littoral area of ASC showed significant differences in none of the contrasted sectors when numerical abundance, richness, and diversity were considered $(\mathrm{p}<0.05)$.

Canonical redundancy analysis (RDA) showed a significant correlation between the fish assemblage, and temperature, dissolved oxygen, $\mathrm{pH}$, and electrical conductivity variables analyzed as a whole $(p=0.04)$. However, this correlation was not significant when each variable was considered separately: Water temperature $(\mathrm{p}=0.08)$; electrical conductivity $(\mathrm{p}=0.18) ; \mathrm{pH}(\mathrm{p}=0.64)$, and dissolved oxygen $(\mathrm{p}=0.33)$.

Through the RDA, multiple regression coefficients between environmental variables were found. Coefficients were lower than 0.7 indicating the absence of highly correlated variables. Temperature $(0.812)$ was the variable that contributed the most to the first canonical axis, followed by oxygen, $\mathrm{pH}$, and conductivity $(-0.4625,0.4276,0.3938$, respectively). The $\mathrm{pH}$ clearly identified the second axis with a negative gradient (-1.0165). Nevertheless, the important contributions of oxygen ( 0.8313$)$ and conductivity (0.6139) were recorded, while the contribution of temperature (0.1614) gained less relevance. In the third axis, conductivity was the variable that contributed the most $(0.7424)$. On this axis the contributions of temperature and oxygen, which influenced negatively $(-0.5453,-0.4243)$, exceeded the $\mathrm{pH}$ value $(0.0064)$.

\section{Discussion}

The representation of the Characiformes and Siluriformes orders found in this study is consistent with the information recorded in the swamp of Ayapel (Ríos-Pulgarín et al., 2008), in a swamp of the Magdalena River floodplain (Arango-Rojas et al., 2008; Granado-Lorencio et al., 2012) and in a lake of the Colombian Amazon (Correa, 2008). Presence in captures of the Characiformes and Siluriformes orders reveal a marked contrast. This contrast may be caused by the capture method that only considered diurnal cycles when some species are more active during nocturnal periods (Arrington \& Winemiller, 2003; Pelicice et al., 2005; Nico 2010). The behavior in the daily activities of fish varies among the different orders. Siluriformes order mostly exhibits a nocturnal habit (Pohlmann et al., 2001; Loures \& Pompeu, 2015). This behavior contrasts with the intense daytime activity of the Characiformes to avoid detection by their predators (Mazzoni \& Rezende, 2009). The plasticity in the patterns of daily activity exhibited by these orders evidences a temporary segregation in the daily activities of the fish that interact with the pleuston communities of the ASC.

Characids represented about half of the total number accounted for by the Characiformes. This trend has also been described for areas of the Neotropical floodplain (Araujo-Lima et al., 1986; Milani et al., 2010). The characids ability to colonize unstable environments and efficiently use the high availability of resources in these biotopes (Willis et al., 2005) explains the numerical importance of this group during the study. The apparent differences in the captures of Characiformes and Gymnotiformes, the dominant orders in the assemblage, were reduced significantly in the case of families where characids predominated in relation to sternopygids. Studies in patches of floating aquatic vegetation in the Amazon basin show how sternopygids are an important component of the nocturnal icthyological fauna associated with plants (Crampton, 1996).

The fish assemblage interacting with floating aquatic plants in the littoral area of the ASC was dominated by opportunistic-omnivore species (Aguirre et al., 2005). The prevalence of omnivorous species, adapted to consume a large variety of resources are favored in the colonization phase and biotope permanent occupation because of their ability to take advantage of an 
abundant and varied food supply (JiménezSegura et al., 2010; Mortillaro et al., 2015). However, within the group of specialist fish, Cyphocharax magdalenae stood out as the major contributor to captured biomass. Nevertheless, this species had a low numerical abundance. The contribution of Cyphocharax magdalenae to biomass was probably a sign of the permanent availability of food originating from the pleuston organic matter and the detritus (Azevedo et al., 2008; Neiff et al., 2009; Santino et al., 2010; Casco et al., 2014).

The contribution of Cyphocharax magdalenae to captures was higher than that recorded for Prochilodus magdalenae and Curimata mivartii, two detritivorous commercial species. In addition, the contribution of Cyphocharax magdalenae to captures could be considered as an indicator of the ecological role that this species has on the function of the ASC. This species might participate in nutrient cycling and energy flow through the detritivorous pathway (Araujo-Lima et al., 1986).

About three quarters of the species captured in the floating plant patches of the ASC used this habitat persistently (C>50\%). The presence of numerous fish species inhabiting the aquatic vegetation in the littoral region of the ASC is likely to be due to the availability of resources in this biotope and the ecological plasticity of fish (Crampton, 1998; Crampton \& Hopkins, 2005; Pelicice et al., 2005; Willis et al., 2005; Soares et al., 2006). The high values estimated for diversity (3.3 bits) could be the consequence of a suitable habitat to support the interacting icthyofauna of these biotopes. This explains the high abundance of species and their persistence over time.

Uniformity of the fish assemblage structure in different sectors of the ASC where the environmental conditions were heterogeneous is associated with the pleuston communities. Likewise, the assemblage similarity between aquatic habitats is consistent with the predominance of generalist fish species that contribute to spatial uniformity. In contrast to the spatial similarity of the fish assemblage structure, significant differences estimated for the attributes of the assemblage between limnimetric moments showed variability in composition and structure over time in a habitat where environmental conditions varied temporally depending on the hydrological cycle.

These temporal differences in the fish assemblage structure are consistent with those reported in tropical flood plains (Suárez et al., 2004). These differences relate to the coverage of aquatic macrophytes in the littoral area of the ASC and the supply of resources associated with variations in the water level (Neiff et al., 2008). Pelicice et al. (2005) reported that in tropical reservoirs the richness of the fish assemblage structure is more affected by the biomass of aquatic plants than by the dissolved oxygen, the water temperature, or the $\mathrm{pH}$.

Similarly, assessed variables including the water temperature, electrical conductivity, $\mathrm{pH}$, and dissolved oxygen did not significantly affect the association of captured fish in the vegetated littoral zone of a swamp located in the flood plain of the Magdalena River (Arango-Rojas et al., 2008). These results are consistent with the results obtained in this study, where the temporal and spatial distribution of fish assemblage structure interacting with the floating plant communities in the littoral area of the ASC was not related to any of the physicochemical variables evaluated separately (Figures 2A and 2B). Considering this, it is probable that, in addition to the combined effect of the variables analyzed and the adaptations of the fish that allow them to successfully deal with cyclical disturbances, the stable environmental conditions in the pleuston interstitial area help in maintaining the similarity of the fish assemblage structure in the ASC. In conclusion, the hypothesis is rejected.

The results of this study confirm the importance of the patches of floating aquatic vegetation in the littoral area of the ASC as an important resource for maintaining fish communities' habitat, considering the adaptive characteristics developed by the fish. These results are important in ecosystems where riparian vegetation is replaced by exotic grasses that grow in large areas, reducing the availability of suitable habitats for the fish fauna.

In attention to the bonds between fish and aquatic vegetation, it is urgent to implement environmental management policies to rehabilitate degraded environments of the ASC. The recovery of the riparian vegetation with native species such as Symmeria paniculata would improve environmental conditions, considering the ecological functions of this species in the ecosystem. This would contribute to maintaining fish communities that are vital to the ecological health of this important aquatic environment, and to the conservation of biodiversity and fishery resources essential for the people of this region. 


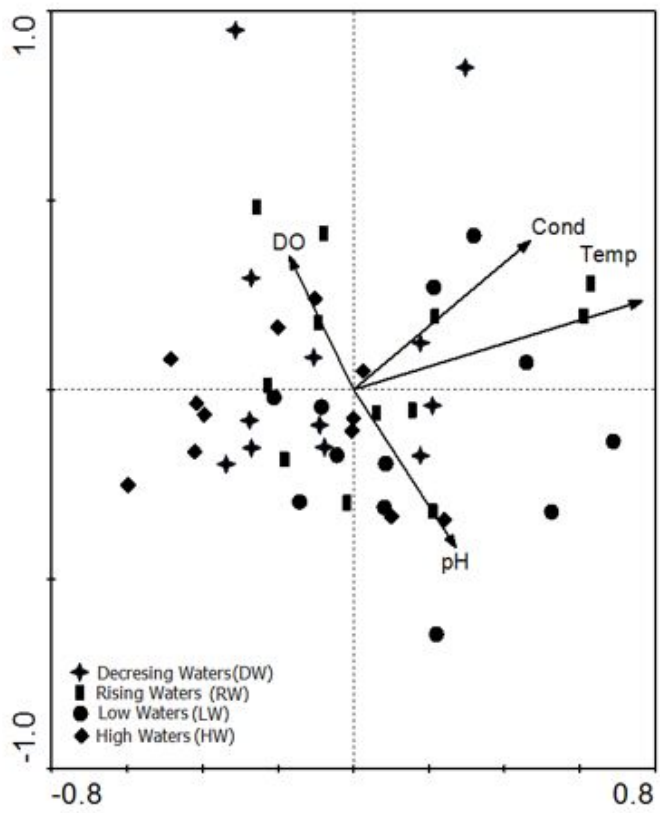

(A)

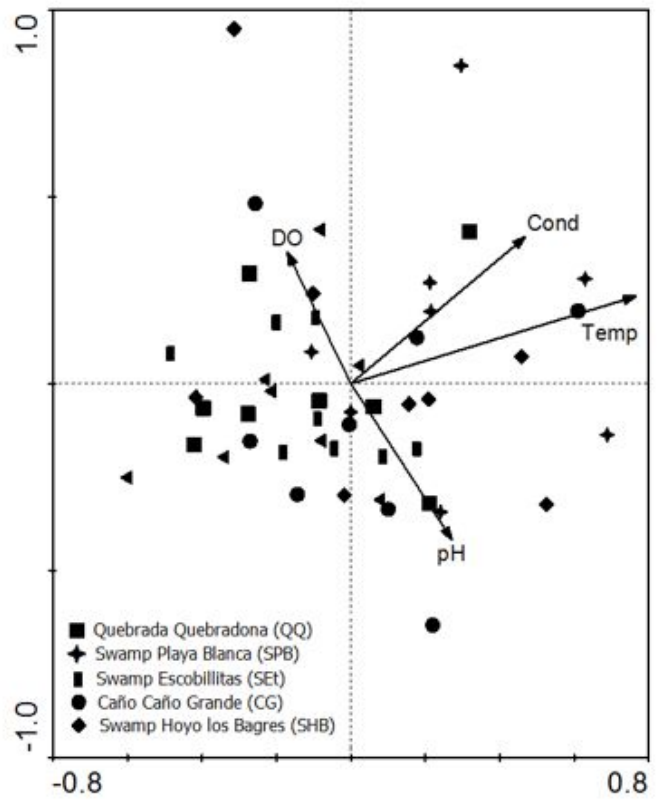

(B)

Figure 2. (A) Graphical representation of Canonical Redundancy Analysis based on the abundance of 44 fish species, environmental variables (Temp = water temperature; Cond = electrical conductivity; $\mathrm{DO}=$ dissolved oxygen; $\mathrm{pH}$ ), and limnimetric moments (geometric figures) during the period January 2008 to June 2009; (B) Graphical representation of Canonical redundancy analysis based on the abundance fish assemblage of 44 fish species, environmental variables $($ Temp $=$ water temperature; Cond = electrical conductivity; $\mathrm{DO}=$ dissolved oxygen; $\mathrm{pH})$, and sampling sectors (geometric figures) during the period-January 2008 to June 2009.

\section{Acknowledgements}

We thank the GAIA Environmental Management and Modeling Research Group of the University of Antioquia for financial support for this work through CODI (Committee for Research Development) sustainability resources. The CORPOAYAPEL foundation helped with logistical support during sampling. The Doctoral program in environmental engineering, Limnology line, of the Faculty of Engineering of the University of Antioquia allowed for interdisciplinary work. The Faculty of Agricultural Sciences supported this educational process. Fishermen provided their effort and commitment in field activities. Carlos Escobar and Dominic Higgins contributed and collaborated in the transcription process of this document.

\section{References}

AGUIRRE, N., PALACIO, J.; FLÓREZ, M., WILLS, A., CAICEDO, O., JIMÉNEZ, L., VILLEGAS, N., GRAJALES, H., PALACIO, C., TORO, M. and VÉLEZ, F. Análisis de la relación rio-ciénaga y su efecto sobre la producción pesquera en el sistema cenagoso de Ayapel, Colombia. Colombia: Universidad de
Antioquia, Universidad Nacional de Colombia, 2005. Informe Técnico COLCIENCIAS 1114-13-13962.

ARANGO-ROJAS, A., JIMÉNEZ-SEGURA, L. and PALACIO-BAENA, J. Variación espaciotemporal de la asociación de especies de peces en la laguna de Cachimbero, un humedal en la cuenca media del río Magdalena, Colombia. Actualidades Biológicas [online], 2008, 30(89), 161-169 [viewed 23 Aug. 2016]. Available from: http://www.scielo. org.co/scielo.php?script=sci_arttext\&pid=S0304$35842008000200005 \& \operatorname{lng}=e s \& n r m=$ iso

ARAUJO-LIMA, C.A., FORSBERG, B.R., VICTORIA, R. and MARTINELLI, L. Energy sources for detritivorous fishes in the Amazon. Science, 1986, 234(4781), 1256-1258. PMid:17778007. http:// dx.doi.org/10.1126/science.234.4781.1256.

ARRINGTON, D.A. and WINEMILLER, K.O. Diel changeover in sandbank fish assemblages in a neotropical floodplain river. Journal of Fish Biology, 2003, 63(2), 442-459. http://dx.doi.org/10.1046/ j.1095-8649.2003.00167.x.

AZEVEDO, J.C., MIZUKAWA, A., TEIXEIRA, M.C. and PAGIORO, T.A. Contribuição da decomposiçẫo de macrófitas aquáticas (Eichhornia azurea) na matéria orgânica dissolvida. Oecologia Brasiliensis, 
2008, 12(1), 42-56. http://dx.doi.org/10.4257/ oeco.2008.1201.04.

CASCO, S.L., CARNEVALI, R.P., POI, A.S.G. and NEIFF, J.J. The influence of water hyacinth floating meadows on limnological characteristics in shallow subtropical waters. American Journal of Plant Sciences, 2014, 5(13), 1983-1994. http://dx.doi.org/10.4236/ ajps.2014.513212.

CORREA, S.B. Fish assemblage structure is consistent through an annual hydrological cycle in habitats of a floodplain-lake in the Colombian Amazon. Neotropical Ichthyology, 2008, 6(2), 257-266. http:// dx.doi.org/10.1590/S1679-62252008000200014.

CRAMPTON, W.G.R. and HOPKINS, C.D. Nesting and paternal care in the weakly electric fish Gymnotus (Gymnotiformes: Gymnotidae) with descriptions of larval and adult electric organs discharges of two species. Copeia, 2005, 1(1), 48-60. http://dx.doi. org/10.1643/CI-04-056R1.

CRAMPTON, W.G.R. Gymnotiform fish: an important component of Amazonian floodplain fish communities. Journal of Fish Biology, 1996, 48(2), 298301. http://dx.doi.org/10.1111/j.1095-8649.1996. tb01122.x.

CRAMPTON, W.G.R. Effects of anoxia on the distribution, respiratory strategies and electric signal diversity of gymnotiform fishes. Journal of Fish Biology, 1998, 53, 307-330, Supplement A. http:// dx.doi.org/10.1111/j.1095-8649.1998.tb01034.x.

DAHL, G. Los peces del Norte de Colombia. 1st ed. Bogotá: Ministerio de Agricultura, Instituto Nacional de los Recursos Naturales Renovables y del Ambiente, 1971.

DAJOZ, R. Tratado de ecología. 2nd ed. Madrid: MundiPrensa, 2002.

EIGENMANN, C.H. The fishes of Northwestern South America, including Colombia, Panamá and the Pacific slopes of the Ecuador and Peru, together with an appendix upon the fishes of the río Meta in Colombia. Memoirs of the Carnegie Museum, 1922, 9(1), 1-346.

GRANADO-LORENCIO, C., SERNA, A.H., CARVAJAL, J.D., JIMÉNEZ-SEGURA, L.F., GULFO, A. and ALVAREZ, F. Regionally nested patterns of fish assemblages in floodplain lakes of the Magdalena river (Colombia). Ecology and Evolution, 2012, 2(6), 1296-1303. PMid:22833801. http:// dx.doi.org/10.1002/ece3.238.

JIMÉNEZ-SEGURA, L., CARVAJAL-QUINTERO, J. and AGUIRRE, N. Las ciénagas como hábitat para los peces: estudio de caso en la Ciénaga de Ayapel (Córdoba), Colombia. Actualidades Biológicas [online], 2010, 32(92), 53-64 [viewed 23 Aug. 2016]. Available from: http://www.scielo. org.co/scielo.php?script=sci_arttext\&pid=S0304$35842010000100005 \& \operatorname{lng}=$ pt\&nrm=iso
JUNK, W.J. and WANTZEN, K.M. The flood pulse concept: new aspects, approaches and applications: an update. In R.L. WELCOMME and T. PETR, eds. Proceedings of the Second International Symposium on the Management of Large Rivers for Fisheries. Bangkok: FAO Regional Office for Asia and the Pacific, 2004, pp. 117-140. Publication 2004/16.

LOPES, T., CUNHA, E., SILVA, J., BEHREND, R. and GOMES, L. Dense macrophytes influence the horizontal distribution of fish in floodplain lakes. Environmental Biology of Fishes, 2015, 98(7), 1741-1755. http://dx.doi.org/10.1007/s10641-0150394-4.

LOURES, R.C. and POMPEU, P.S. Seasonal and diel changes in fish distribution in a tropical hydropower plant tailrace: evidence from hydroacoustic and gillnet sampling. Fisheries Management and Ecology, 2015, 22(3), 185-196. http://dx.doi.org/10.1111/ fme. 12116 .

MALDONADO-OCAMPO, J. A., ORTEGA-LARA, A., USMA-O., J. S., GALVIS-V., G., VILLANAVARRO, F. A., VÁSQUEZ-G., L., PRADAPEDREROS, S. and. ARDILA-RODRÍGUEZ, C. A. Peces de los Andes de Colombia. 1st ed. Bogotá: Instituto de Investigación de Recursos Biológicos Alexander Von Humboldt, 2005.

MAZZONI, R. and REZENDE, C.F. Daily feeding activity of Bryconamericus microcephalus (Characiformes, Characidae) from Córrego Andorinha, Ilha Grande. Brazilian Journal of Biology = Revista Brasileira de Biologia, 2009, 69(2), 381-384. PMid:19675942. http://dx.doi.org/10.1590/S151969842009000200021.

MILANI, V., MACHADO, F.A. and SILVA, V.C.F. Assembléias de peixes associados às macrófitas aquáticas em ambientes alagáveis do Pantanal de Poconé, MT, Brasil. Biota Neotropica, 2010, 10(2), 261-270. http://dx.doi.org/10.1590/S167606032010000200029.

MOJICA, J.I., USMA, J.S., ÁLVAREZ-LEÓN, R. and LASSO, C.A. Libro Rojo de peces dulceacuicolas de Colombia. 1st ed. Bogotá: Instituto de Investigaciones de Recursos Biológicos Alexander von Humboldt, 2012.

MONTOYA, Y. and AGUIRRE, N. Estado del arte de la limnología de lagos de planos inundables (ciénagas) en Colombia. Revista Gestión y Ambiente, 2009, 12(3), 85-106.

MONTOYA-MORENO, Y. and AGUIRRERAMÍREZ, N. Asociación de algas perifíticas en raíces de macrófitas en una ciénaga tropical Colombiana. Hidrobiológica, 2009, 18(3), 189-198.

mortillaro, J., POUIlly, M., WACH, M., FREITAS, C., ABRIL, G. and MEZIANE, T. Trophic opportunism of central Amazon floodplain fish. Freshwater Biology, 2015, 60(8), 1659-1670. http://dx.doi.org/10.1111/fwb.12598. 
NEIFF, J.J., CASCO, S.L. and POI DE NEIFF, A. Response of Eichhornia crassipes (Pontederiaceae) to water level fluctuations in two lakes with different connectivity in the Paraná River floodplain. Revista de Biologia Tropical, 2008, 56(2), 613-623. PMid:19256432.

NEIFF, J.J., NEIFF, A.P. and VERÓN, M.B.C. The role of vegetated areas on fish assemblage of the Paraná River floodplain: effects of different hydrological conditions. Neotropical Ichthyology, 2009, 7(1), 39-48. http://dx.doi.org/10.1590/ S1679-62252009000100006.

NELSON, J.S., GRANDE, T.C. and WILSON, M.V.H. Fishes of the world. 5th ed. New Jersey: John Wiley \& Sons, 2006.

NICO, L.G. Nocturnal and diurnal activity of armored suckermouth catfish (Loricariidae: Pterygoplichthys) associated with wintering Florida manatees (Trichechus manatus latirostris). Neotropical Ichthyology, 2010, 8(4), 893-898. http://dx.doi.org/10.1590/S167962252010005000014

PELICICE, F.M., AGOSTINHO, A.A. and THOMAZ, S.M. Fish assemblages associated with Egeria in a tropical reservoir: investigating the effects of plant biomass and diel period. Acta Oecologica, 2005, 27(1), 9-16. http://dx.doi.org/10.1016/j. actao.2004.08.004.

PÉREZ-MAYORGA, A. and PRADA-PEDREROS, S. Relación entre comunidad íctica y cobertura vegetal riparia en dos períodos hidrológicos (Eje Cafetero, Colombia). Universitas Scientiarum, 2011, 16(2), 119-139. http://dx.doi.org/10.11144/javeriana. SC16-2.rbfc.

POHLMANN, K., GRASSO, F.W. and BREITHAUPT, T. Tracking wakes: The nocturnal predatory strategy of piscivorous catfish. Proceedings of the National Academy of Sciences of the United States of America, 2001, 98(13), 7371-7374. PMid:11390962. http:// dx.doi.org/10.1073/pnas.121026298.

POI DE NEIFF, A. and NEIFF, J.J. Riqueza de especies y similaridad de los invertebrados que viven en plantas flotantes de la planicie de inundación del Río Paraná (Argentina). Interciencia [online], 2006, 31(3), 220225 [viewed 23 Aug. 2016]. Available from: http:// www.redalyc.org/articulo.oa?id=33911411.

PUSEY, B.J. and ARTHINGTON, A.H. Importance of the riparian zone to the conservation and management of freshwater fish: a review. Marine \& Freshwater Research, 2003, 54(1), 1-16. http://dx.doi. org/10.1071/MF02041.

REDDY, K.R. and TUCKER, W.F. Productivity and nutrient uptake of water hyacinth, Eichhornia crassipes: I-Effect of nitrogen source. Economic Botany, 1983, 37(2), 237-247. http://dx.doi. org/10.1007/BF02858790.
RÍOS-PULGARÍN, M.I., JIMÉNEZ-SEGURA, L.F., PALACIO-BAENA, J.A. and RAMÍREZRESTREPO, J.J. Comunidad de peces en la Ciénaga de Ayapel, Río Magdalena (Córdoba) Colombia: cambios espacio-temporales en su asociación. Actualidades Biológicas, 2008, 30(88), 29-53.

RIVERA-RONDÓN, C., PRADA-PEDREROS, S., GALINDO, D. and MALDONADO-OCAMPO, $J$. Effects of aquatic vegetation on the spatial distribution of Grundulus bogotensis, Humboldt 1821 (CHARACIFORMES: CHARACIDAE). Caldasia, 2008, 30(1), 135-150.

SÁNCHEZ-BOTERO, J.I., LEITÃO, R.P., CARAMASCHI, E.P. and GARCEZ, D.S. The aquatic macrophytes as refuge, nursery and feeding habitats for freshwater fish from Cabiúnas lagoon, restinga de Jurubatiba National Park, Rio de Janeiro, Brazil. Acta Limnologica Brasiliensia, 2007, 19(2), 143-153.

SANTINO, M.B.C., BIANCHINI JUNIOR, I. and OKAWA, M.H. The fate of Eichhornia azurea (Sw.) Kunth. detritus within a tropical reservoir. Acta Limnologica Brasiliensia, 2010, 22(2), 109-121. http://dx.doi.org/10.1590/S2179975X2010000200001.

SCHMIDT-MUMM, U. and JANAUER, G. Seasonal dynamics of the shoreline vegetation in the Zapatosa floodplain lake complex, Colombia. Revista de Biologia Tropical, 2014, 62(3), 1073-1097. PMid:25412537. http://dx.doi.org/10.15517/rbt.v62i3.12005.

SOARES, M.G.M., MENEZES, N.A. and JUNK, W.J. Adaptations of fish species to oxygen depletion in a central Amazonian floodplain lake. Hydrobiologia, 2006, 568(1), 353-367. http://dx.doi.org/10.1007/ s10750-006-0207-z.

SUÁREZ, Y.R., PETRERE, M. Jr. and CATELLA, A.C. Factors regulating diversity and abundance of fish communities in Pantanal lagoons, Brazil. Fisheries Management and Ecology, 2004, 11(1), 45-50. http:// dx.doi.org/10.1111/j.1365-2400.2004.00347.x.

TER BRAAK, C.J.F. and ŠMILAUER, P. CANOCO Reference Manual and CanoDraw for Windows User's Guide: Software for Canonical Community Ordination (version 4.5). Ithaca: Microcomputer Power, 2012.

THOMAZ, S.M. and CUNHA, E.R. The role of macrophytes in habitat structuring in aquatic ecosystems: methods of measurement, causes and consequences on animal assemblages' composition and biodiversity. Acta Limnologica Brasiliensia, 2010, 22(2), 218-236. http://dx.doi.org/10.4322/ actalb.02202011.

USMA, J., VALDERRAMA, M., ESCOBAR, M., AJIACO-MARTÍNEZ, R., VILLA-NAVARRO, F., CASTRO, F., RAMÍREZ-GIL, H., SANABRIA, A., ORTEGA-LARA, A., MALDONADOOCAMPO, J., ALONSO, J. and CIPAMOCHA, C. Peces dulceacuícolas migratorios. In MINISTRO 
DE AMBIENTE, VIVIENDA Y DESARROLLO TERRITORIAL, WWF Colombia, eds. Plan Nacional de las especies migratorias. Diagnóstico e identificación de acciones para la conservación y el manejo sostenible de las especies migratorias de la biodiversidad en Colombia. 1st ed. Bogotá: WWF Colombia, 2009, pp. 103-131.

VILLABONA-GONZÁLEZ, S., AGUIRRE, N. and ESTRADA, A. Influencia de las macrófitas sobre la estructura poblacional de rotíferos y microscrustáceos en un plano de inundación tropical. Revista de Biologia Tropical, 2011, 59(2), 853-870. PMid:21721243.
WILLIS, S.C., WINEMILLER, K.O. and LOPEZFERNANDEZ, H. Habitat structural complexity and morphological diversity of fish assemblages in a Neotropical floodplain river. Oecologia, 2005, 142(2), 284-295. PMid:15655689. http://dx.doi. org/10.1007/s00442-004-1723-z.

Received: 23 August 2016 Accepted: 07 February 2017 